\title{
Editorial
}

\section{Sustainable Construction Engineering and Management}

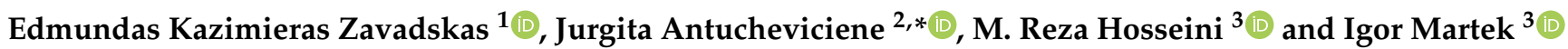 \\ 1 Institute of Sustainable Construction, Vilnius Gediminas Technical University, LT-10223 Vilnius, Lithuania; \\ edmundas.zavadskas@vilniustech.lt \\ 2 Department of Construction Management and Real Estate, Vilnius Gediminas Technical University, \\ LT-10223 Vilnius, Lithuania \\ 3 School of Architecture and Built Environment, Deakin University, Geelong, VIC 3220, Australia; \\ reza.hosseini@deakin.edu.au (M.R.H.); igor.martek@deakin.edu.au (I.M.) \\ * Correspondence: jurgita.antucheviciene@vilniustech.lt
}

\section{check for}

updates

Citation: Zavadskas, E.K. Antucheviciene, J.; Hosseini, M.R.; Martek, I. Sustainable Construction Engineering and Management. Sustainability 2021, 13, 13028. https: / / doi.org/10.3390/ su132313028

Received: 17 November 2021 Accepted: 22 November 2021 Published: 25 November 2021

Publisher's Note: MDPI stays neutral with regard to jurisdictional claims in published maps and institutional affiliations.

Copyright: (c) 2021 by the authors. Licensee MDPI, Basel, Switzerland. This article is an open access article distributed under the terms and conditions of the Creative Commons Attribution (CC BY) license (https:/ / creativecommons.org/licenses/by/ $4.0 /)$.

\begin{abstract}
The Special Issue covers sustainability as an emerging requirement in the fields of construction management, project management and engineering. We invited authors to submit their theoretical or experimental research articles that address the challenges and opportunities for sustainable construction in all its facets, including technical topics and specific operational or procedural solutions, as well as strategic approaches aimed at the project, company or industry level. Central to developments are smart technologies and sophisticated decision-making mechanisms that augment sustainable outcomes. The Special Issue was received with great interest by the research community and attracted a high number of submissions. The selection process sought to balance the inclusion of a broad representative spread of topics against research quality, with editors and reviewers settling on thirty-three articles for publication. The Guest Editors invite all participating researchers and those interested in sustainable construction engineering and management to read this summary of the Special Issue and of course to access the full-text articles for deeper analyses.
\end{abstract}

Keywords: sustainability; construction management; project management; design; materials; maintenance; smart technologies; decision-making methods

\section{Introduction}

The 20th century was an age of unprecedented growth in the use of natural resources and materials. Global demand for materials grew during that century, following the steady economic growth in OECD_-Organization for Economic Co-operation and Developmentcountries, the industrialization of emerging economies and a growing world population [1,2]. At the global level, the extraction of raw materials more than doubled between 1990 and 2017 and is projected to double again by 2060. These recent trends, however, will not be enough to counteract the rising demands and ongoing quest for higher living standards of a world population headed to more than 10 billion by 2060, of whom more than $75 \%$ are expected to live in urban areas [3].

Three socio-economic factors generally drive the use of materials and resources. First, a growing global population and the progressive convergence in living standards across countries lead to higher consumption, thus increasing materials use. Furthermore, as economies develop, investments in construction and infrastructure increase, leading to a higher demand for materials [4,5]. Second, technological improvements reduce energy consumption, which can decrease the material intensity of production [1], thus reducing the materials input required to produce a given economic good. For instance, prefabrication, as an advanced construction technology, is more resource-efficient (requiring less material and generating less waste) and performs better economically than previous methods [6,7]. Third, with structural changes in the landscape of the overarching economy, the material intensity of the economy can be further reduced. As specified in a recent OECD report, as income levels rise, aggregate demand shifts towards less resource-intensive sectors, such 
as services and leisure activities [2]. Overall, technological advancements and structural changes have the potential to counterbalance the increasing demand for materials use, partially decoupling materials use from economic growth $[7,8]$.

In recent years, countries have demonstrated a stronger interest in resource efficiency, not only to address environmental issues but also to achieve objectives such as economic growth as well as employment and resource security [9]. Sustainability is currently more than a fad or fashion that engineers and construction managers can choose to embrace if they wish or ignore if they prefer to focus on traditional core competencies. It has become a moral imperative, a global political priority [10]. It is the benchmark by which 'good, socially responsible' companies are measured and given a pass or fail. Engineering and construction firms can no longer afford to ignore the call to take up the 'sustainability cause,' lest they become ostracized and labeled irresponsible.

If that view seems extreme, consider current developments. The Gudamalulgal indigenous community that inhabit the Boigu and Saibai islands of the Torres Strait, Northern Australia have brought a High Court case against the Australian Federal Government, claiming that Australian inaction is causing 'catastrophic climate change' that threatens the livelihoods of the island people [11]. This is despite the fact that Australia's contribution to world $\mathrm{CO}_{2}$ emissions is only $1 \%$ of the world's total [12]. The point is that adopting a disinterested or neutral position regarding activist community demands in relation to sustainability concerns is no longer possible.

The challenge is not limited to the political arena but has bled into corporate activities as well. A Netherlands court has ruled that the global conglomerate, Royal Dutch Shell, must reduce its carbon emissions by $45 \%$ by 2030 . The ruling applies not only to the company itself but to suppliers and ominously to emissions generated by all its customers worldwide. The court's judgment can be expected to set a precedent-and a warningto companies everywhere, that they must fall in line in addressing sustainability and in mitigating climate change. Sara Shaw, a spokesperson for 'Friends of the Earth International' commented, "Our hope is that this verdict will trigger a wave of climate litigation against big polluters." [13].

The biggest polluters are in fact the construction industry [14]. Globally, the built environment eats up a full one-third of all the world's raw materials. Specifically, the fabrication of buildings consumes one-sixth of all freshwater, one-third of all timber, and four-fifths of everything else. Buildings, too, are the biggest users of energy. One-tenth of the world's energy goes into making building materials. Then, just to keep the lights on and heating running, buildings absorb a full one-half of all the energy generated in the world $[15,16]$. Nothing comes close to impacting the planet more adversely than the construction industry does, and attention is being drawn to this uncomfortable fact.

Firms operating in the construction sector are increasingly well aware of their impact. Many, however, have found it difficult to respond. For one, the construction industry is notoriously bad at innovation, particularly when it comes to matters of improving materials, waste and energy efficiencies [4,17]. Second, becoming sustainable is expensive - up to double the cost-and few business models in the sector have managed to identify who it is that would gladly pay for more expensive, 'green buildings;' most clients would certainly not.

Multiple-criteria decision-making (MCDM) methods can be helpful in resolving the contradictory aims of politics and industry. They are especially valuable in identifying compromise solutions in the area of sustainability, including sustainability engineering [18], civil engineering, construction and building technology $[19,20]$. The most frequently used hybrid decision-making methods harness the advantages of hybrid approaches over individual methods, and they can assist decision-makers in handling information such as stakeholders' preferences, interconnected or contradictory criteria, and uncertain environments [21]. A variety of fuzzy multiple-criteria decision-making models have been proposed to solve complicated decision-making problems. Many fuzzy MCDM applications have been utilized in the field of civil engineering and management [22], 
including in construction project selection [23], construction safety risk assessment [24] and supplier selection [25].

Ultimately, one question remains: What practical measures can industry practitioners adopt that meaningfully embrace the sustainability agenda and improve the industry's performance?

The Special Issue on 'sustainability as an emerging requirement in the fields of construction management, project management and engineering' is an effort to answer that question. Experts in their various capacities were invited to comment and report on the latest innovations and breakthroughs being made in the construction industry that would make it more sustainable. Their many insightful contributions are reported here-some 33 papers. Interested readers are invited to review the titles summarized in Table 1 and to download and examine those papers that hold a particular interest for them. They are, of course, all worth a close read.

Table 1. Contributions by research areas and applied solution methods/technologies.

\begin{tabular}{|c|c|c|}
\hline Contributions & $\begin{array}{l}\text { Research } \\
\text { Area/Object }\end{array}$ & $\begin{array}{c}\text { Applied/Developed } \\
\text { Solution Methods/Technologies }\end{array}$ \\
\hline Contribution 1 & Risk management in infrastructure projects & IDEFO (Integration Definition for Function Modeling) \\
\hline Contribution 2 & Management and evaluation of construction projects & AHP (Analytic Hierarchy Process), Decision Tree \\
\hline Contribution 3 & Digitalization of construction & Review paper \\
\hline Contribution 4 & Evaluation of life cycle of residential buildings & Environmental impact in terms of $\mathrm{CO}_{2}$ emissions, etc. \\
\hline Contribution 5 & Infrastructure maintenance, decision-making & Optimization \\
\hline Contribution 6 & PPP sustainability, critical success factors & Fuzzy synthetic evaluation \\
\hline Contribution 7 & Fly ash geopolymer in construction industry & $\begin{array}{c}\text { COLA (Cross-organizational approach), systematic } \\
\text { literature review }\end{array}$ \\
\hline Contribution 8 & Highway construction projects & Triangular intuitionistic fuzzy decision-making \\
\hline Contribution 9 & Selection of building insulation materials & Systematic literature review of MCDM applications \\
\hline Contribution 10 & Public construction; data auto correction system & Machine learning, natural data processing \\
\hline Contribution 11 & $\begin{array}{l}\text { Modernization of construction industry, } \\
\text { organizational innovation, enterprise competitiveness }\end{array}$ & SEM (Structural Equation Modeling) \\
\hline Contribution 12 & Ranking of green materials & $\begin{array}{l}\text { SWARA (Stepwise Weight Assessment Ratio Analysis), } \\
\text { COPRAS (Complex Proportional Assessment) }\end{array}$ \\
\hline Contribution 13 & $\begin{array}{l}\text { Building projects' sustainable value management in } \\
\text { developing countries }\end{array}$ & EFA (Exploratory Factor Analysis) \\
\hline Contribution 14 & Reworks of building construction projects & SWARA, BIM (Building Information Modeling) \\
\hline Contribution 15 & Construction project scheduling & Resource constrained critical path method \\
\hline Contribution 16 & Construction management & Last Planner System \\
\hline Contribution 17 & Probabilistic structural design & $\begin{array}{l}\text { Sensitivity analysis, uncertainty modeling, stochastic } \\
\text { simulation }\end{array}$ \\
\hline Contribution 18 & Bridge construction, risk assessment & Loss assessment model \\
\hline Contribution 19 & Risk delay in construction projects & Artificial intelligence, random forest genetic algorithm \\
\hline Contribution 20 & $\begin{array}{l}\text { Green buildings, LEED (Leadership in Energy and } \\
\text { Environmental Design) credits }\end{array}$ & Analysis of LEED certificated projects \\
\hline Contribution 21 & Integrated design process of modular construction & $\begin{array}{c}\text { DS/m (Dependency Structure Matrix) process } \\
\text { optimization }\end{array}$ \\
\hline Contribution 22 & Roof installation projects & AHP (Analytic Hierarchy Process), Decision Tree \\
\hline Contribution 23 & Defect management in residential buildings & LDA (Loss Distribution Approach) \\
\hline Contribution 24 & Facility management & $\begin{array}{l}\text { BIM, BPA (Building Performance Assessment), KPIS } \\
\text { (Key } \\
\text { Performance Indicators), etc. }\end{array}$ \\
\hline
\end{tabular}


Table 1. Cont.

\begin{tabular}{lcc}
\hline Contributions & $\begin{array}{c}\text { Research } \\
\text { Area/Object }\end{array}$ & $\begin{array}{c}\text { Applied/Developed } \\
\text { Solution Methods/Technologies }\end{array}$ \\
\hline Contribution 25 & Safety knowledge transfer in construction industry & SEM (Structural Equation Modeling) \\
\hline Contribution 26 & Power construction projects & Time management, delay management, expert survey \\
\hline Contribution 27 & Metro line project management & Set pair analysis \\
\hline Contribution 28 & Bridge deterioration prediction & $\begin{array}{c}\text { Semi-Markov process, } \\
\text { Weibull distribution }\end{array}$ \\
\hline Contribution 29 & LEED certificated projects; challenges for general \\
& contractor & $\begin{array}{c}\text { Review of projects, } \\
\text { expert survey }\end{array}$ \\
\hline Contribution 30 & Concrete temperature monitoring in high-rise building \\
constructions & $\begin{array}{c}\text { WSN } \\
\text { Contribution 31 }\end{array}$ & Risks in construction PPP (Public-private partnership) \\
projects & $\begin{array}{c}\text { Integrated FISM (fuzzy interpretative structural } \\
\text { multiplication applied to a classification) approach, } \\
\text { triangular fuzzy numbers }\end{array}$ \\
\hline Contribution 32 & Bridge management system based on BIM & $\begin{array}{c}\text { (Wireless sensor network) } \\
\text { (International Framework for Dictionaries) }\end{array}$ \\
\hline Contribution 33 & Sustainable project management & $\begin{array}{c}\text { BIM, TAM (Technology Acceptance Model), TOE } \\
\text { (Technology-Organization-Environment), SEM }\end{array}$ \\
\hline
\end{tabular}

\section{Contributions}

After careful evaluation, thirty-three papers were accepted and published in the Special Issue.

The Special Issue raised the interest of researchers from various scientific schools all over the world. Submissions came in from Europe, Asia, North and South America, Australia, and Africa. One hundred and twenty-five researchers from nineteen different countries contributed to the published papers (Figure 1). The greatest number of submissions came from Asia (China and Korea) followed by Lithuania. There was a strong representation comprising of six to eight authors from Taiwan, Australia, Iran and Saudi Arabia. The remaining countries fielded between one to three authors.

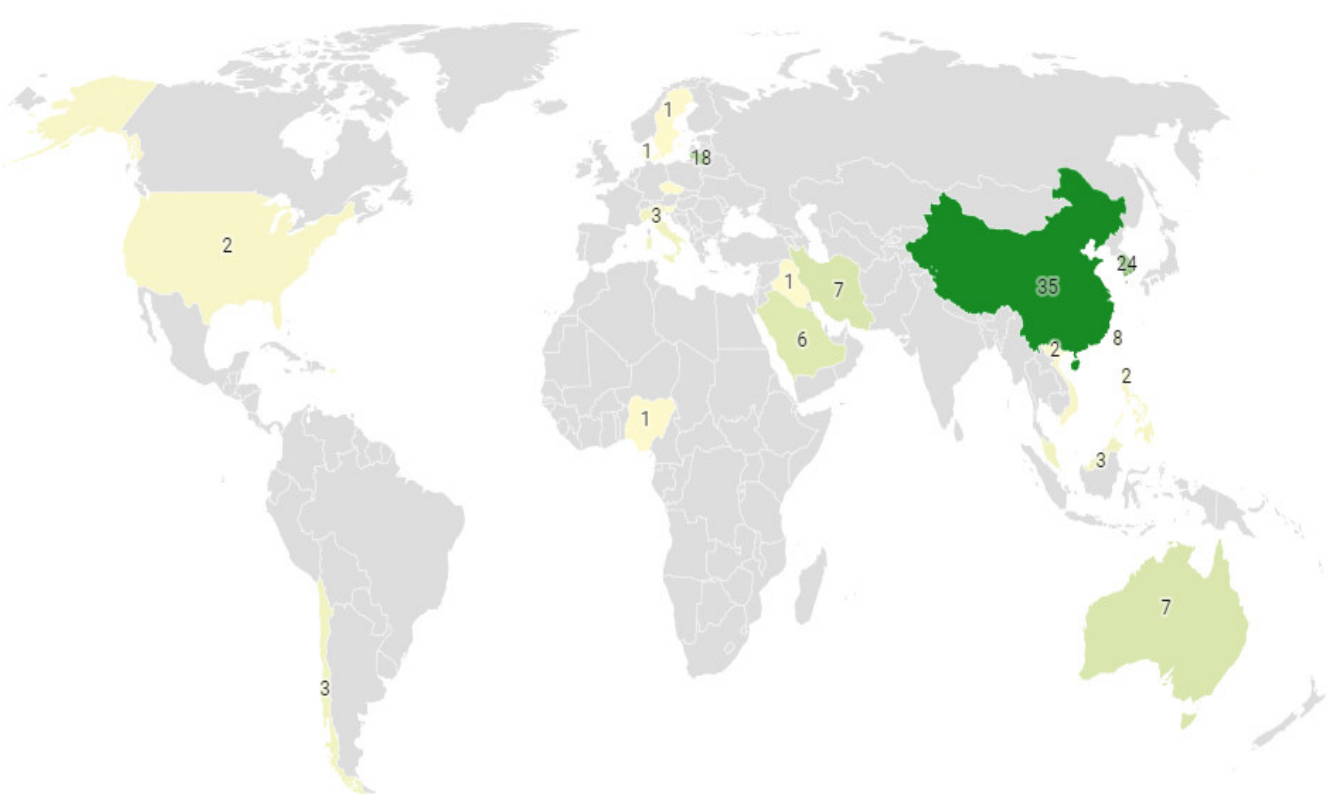

Figure 1. The number of authors from different countries. 
Though authors from nineteen countries contributed to the Special Issue, national research collectives dominated. Almost two-thirds of the publications were authored by researchers from one country (twenty-one papers). Twelve papers were prepared by international co-authors' collectives, usually consisting of researchers from two or three countries.

The authors proposed various solution methods or advanced technologies in order to deal with matters that addressed sustainable development in construction engineering or management (Table 1).

Several papers proposed different multiple-criteria decision-making models (Contributions 2, 12, 14, 22 and 31), often dealing with uncertain data and applying fuzzy modeling (Contributions 6, 8 and 31). Other papers analyzed the application of modern construction digitalization techniques in terms of BIM (Building Information Modeling) (Contributions 3, 14, 24, 32 and 33), artificial intelligence (Contribution 19) and wireless sensors (Contribution 30). Two papers performed expert surveys and analyzed the results (Contributions 26 and 29), and three papers undertook systematic literature reviews of their research areas (Contributions 3, 7 and 9).

The application fields of the proposed/applied solution models or technologies involved different civil engineering and management problems, including risk management (Contributions 1, 18, 19 and 31), life cycle management (Contribution 4), key performance indicators (Contributions 6 and 24), value management (Contribution 13) and loss assessment (Contributions 18 and 23), project scheduling (Contribution 15), time and delay management (Contribution 26) and reworks (Contribution 14). Two papers analyzed the LEED building certification system (Contributions 20 and 29). One paper (Contribution 16) was focused on the Last planner system.

The construction object forms that were analyzed comprised a very wide range, including residential buildings (Contributions 5 and 33), public construction (Contribution 10), various infrastructure objects (Contributions 1 and 5) such as highways (Contribution 8), metro lines (Contribution 27) and bridges (Contributions 18, 28 and 32), power constructions (Contribution 26), as well as high-rise buildings (Contribution 30). Some of the papers analysed construction materials' performance or their selection (Contributions 7, 9 and 12). Several others considered the managerial aspects of construction enterprises or public-private partnerships (Contributions 6, 11 and 31).

\section{Conclusions}

'Sustainability' is at once a new concept but one with a long history. Its meaning has evolved over time. The premise that humankind can impact the planet on which we live can be said to originate with God's command to Adam and Eve to 'go forth and subdue the Earth'. A zeal to exploit the globe's riches of gold, spices and materials is what drove the great colonial expansions of the 15 th through 18 th centuries. Then, in 1798 , the mathematician Robert Malthus warned that exponential population growth was soon going to collide with the hard reality that the Earth's resources were both finite and depleting. In the mid-20th century, we became concerned with rising pollution, then old-growth forest decimation, then acid rain, and then the disintegration of the ozone layer. Through the 1970s, the problem was not that we were using fossil fuels too much but that there were not enough petroleum reserves to keep cars moving and the lights on into the next generation. More recently, the problem has metamorphosed into the familiar rally to fight 'global warming.' We were warned that temperatures would rise, rains would cease and that water resources would dry up. As it turns out, we are getting the rain, so now the preferred euphemism is 'climate change' [16,26].

While the perceived nature of the threat to our planet has shifted over time and will no doubt shift again, the fact remains that the global community is crying out for action. Thus, such concerns-no matter whether real or uncertain-must be responded to and met. As noted in the introduction, the construction industry is the one global sector with a massively disproportionate negative impact on the environment and on people. Architects, engineers, builders and project managers have no alternative but to take up 
the sustainability cause. The excuse according to which the way forward is unknown and uncharted is no longer valid. Society expects the industry to shift. The list of readings provided here is an enlightened and refreshingly optimistic collection of strategies for bringing the construction industry into the 21st century of socially responsible engineering and building.

\section{List of Contributions:}

1. Tserng, H.-P.; Cho, I.-C.; Chen, C.-H.; Liu, Y.-F. Developing a Risk Management Process for Infrastructure Projects Using IDEF0.

2. Maceika, A.; Bugajev, A.; Šostak, O.R.; Vilutienè, T. Decision Tree and AHP Methods Application for Projects Assessment: A Case Study.

3. Nikmehr, B.; Hosseini, M.R.; Martek, I.; Zavadskas, E.K.; Antucheviciene, J. Digitalization as a Strategic Means of Achieving Sustainable Efficiencies in Construction Management: A Critical Review.

4. Alhazmi, H.; Alduwais, A.K.; Tabbakh, T.; Aljamlani, S.; Alkahlan, B.; Kurdi, A. Environmental Performance of Residential Buildings: A Life Cycle Assessment Study in Saudi Arabia.

5. Yang, Y.; Xie, H. Determination of Optimal MR\&R Strategy and Inspection Intervals to Support Infrastructure Maintenance Decision Making.

6. Deng, B.; Zhou, D.; Zhao, J.; Yin, Y.; Li, X. Fuzzy Synthetic Evaluation of the Critical Success Factors for the Sustainability of Public Private Partnership Projects in China.

7. Ongpeng, J.M.C.; Guades, E.J.; Promentilla, M.A.B. Cross-Organizational Learning Approach in the Sustainable Use of Fly Ash for Geopolymer in the Philippine Construction Industry.

8. Hashemi, H.; Ghoddousi, P.; Nasirzadeh, F. Sustainability Indicator Selection by a Novel Triangular Intuitionistic Fuzzy Decision-Making Approach in Highway Construction Projects.

9. Siksnelyte-Butkiene, I.; Streimikiene, D.; Balezentis, T.; Skulskis, V. A Systematic Literature Review of Multi-Criteria Decision-Making Methods for Sustainable Selection of Insulation Materials in Buildings.

10. Yu, M.-L.; Tsai, M.-H. ACS: Construction Data Auto-Correction System-Taiwan Public Construction Data Example.

11. Ni, G.; Xu, H.; Cui, Q.; Qiao, Y.; Zhang, Z.; Li, H.; Hickey, P.J. Influence Mechanism of Organizational Flexibility on Enterprise Competitiveness: The Mediating Role of Organizational Innovation.

12. Balali, A.; Valipour, A.; Zavadskas, E.K.; Turskis, Z. Multi-Criteria Ranking of Green Materials According to the Goals of Sustainable Development.

13. Kineber, A.F.; Othman, I.; Oke, A.E.; Chileshe, N.; Buniya, M.K. Identifying and Assessing Sustainable Value Management Implementation Activities in Developing Countries: The Case of Egypt.

14. Khalesi, H.; Balali, A.; Valipour, A.; Antucheviciene, J.; Migilinskas, D.; Zigmund, V. Application of Hybrid SWARA-BIM in Reducing Reworks of Building Construction Projects from the Perspective of Time.

15. Kim, K. Generalized Resource-Constrained Critical Path Method to Improve Sustainability in Construction Project Scheduling.

16. Salazar, L.A.; Arroyo, P.; Alarcón, L.F. Key Indicators for Linguistic Action Perspective in the Last Planner ${ }^{\circledR}$ System.

17. Kala, Z. Sensitivity Analysis in Probabilistic Structural Design: A Comparison of Selected Techniques.

18. Ahn, S.; Kim, T.; Kim, J.-M. Sustainable Risk Assessment through the Analysis of Financial Losses from Third-Party Damage in Bridge Construction.

19. Yaseen, Z.M.; Ali, Z.H.; Salih, S.Q.; Al-Ansari, N. Prediction of Risk Delay in Construction Projects Using a Hybrid Artificial Intelligence Model. 
20. Pham, D.H.; Kim, B.; Lee, J.; Ahn, A.C.; Ahn, Y. A Comprehensive Analysis: Sustainable Trends and Awarded LEED 2009 Credits in Vietnam.

21. Hyun, H.; Kim, H.; Lee, H.-S.; Park, M.; Lee, J. Integrated Design Process for Modular Construction Projects to Reduce Rework.

22. Maceika, A.; Bugajev, A.; Šostak, O.R. The Modelling of Roof Installation Projects Using Decision Trees and the AHP Method.

23. Kim, B.; Ahn, Y.; Lee, S. LDA-Based Model for Defect Management in Residential Buildings.

24. Marmo, R.; Nicolella, M.; Polverino, F.; Tibaut, A. A Methodology for a Performance Information Model to Support Facility Management.

25. Huang, Y.-H.; Yang, T.-R. Exploring On-Site Safety Knowledge Transfer in the Construction Industry.

26. Banobi, E.T.; Jung, W. Causes and Mitigation Strategies of Delay in Power Construction Projects: Gaps between Owners and Contractors in Successful and Unsuccessful Projects.

27. Dong, N.; Fu, Y.; Xiong, F.; Li, L.; Ao, Y.; Martek, I. Sustainable Construction Project Management (SCPM) Evaluation-A Case Study of the Guangzhou Metro Line-7, PR China.

28. Fang, Y.; Sun, L. Developing A Semi-Markov Process Model for Bridge Deterioration Prediction in Shanghai.

29. Pham, D.H.; Lee, J.; Ahn, Y. Implementing LEED v4 BD+C Projects in Vietnam: Contributions and Challenges for General Contractor.

30. Lim, H.; Kim, T. Smartphone-Based Data Collection System for Repetitive Concrete Temperature Monitoring in High-Rise Building Construction.

31. Jiang, X.; Lu, K.; Xia, B.; Liu, Y.; Cui, C. Identifying Significant Risks and Analyzing Risk Relationship for Construction PPP Projects in China Using Integrated FISMMICMAC Approach.

32. Wan, C.; Zhou, Z.; Li, S.; Ding, Y.; Xu, Z.; Yang, Z.; Xia, Y.; Yin, F. Development of a Bridge Management System Based on the Building Information Modeling Technology.

33. Yuan, H.; Yang, Y.; Xue, X. Promoting Owners' BIM Adoption Behaviors to Achieve Sustainable Project Management.

Author Contributions: All authors contributed equally to this work. All authors have read and agreed to the published version of the manuscript.

Funding: This research received no external funding.

Institutional Review Board Statement: Not applicable.

Informed Consent Statement: Not applicable.

Data Availability Statement: Data sharing not applicable.

Acknowledgments: Authors express their gratitude to the journal Sustainability.

Conflicts of Interest: The authors declare no conflict of interest.

\section{References}

1. Shooshtarian, S.; Hosseini, M.R.; Kocaturk, T.; Ashraf, M.; Arnel, T.; Doerfler, J. The Circular Economy in the Australian Built Environment: The State of Play and a Research Agenda; Deakin University: Geelong, VIC, Australia, 2021; ISBN 978-0-7300-0405-9.

2. OECD. Improving Resource Efficiency and the Circularity of Economies for a Greener World; Organisation for Economic Cooperation and Development: Paris, France, 2020. Available online: https:/ / doi.org/10.1787/1b38a38f-en (accessed on 6 November 2021).

3. Bibas, R.; Chateau, J.; Lanzi, E. Policy Scenarios for a Transition to a More Resource Efficient and Circular Economy; Organisation for Economic Co-Operation and Development: Paris, France, 2021; p. 81. [CrossRef]

4. Adabre, M.A.; Chan, A.P.; Darko, A. Interactive effects of institutional, economic, social and environmental barriers on sustainable housing in a developing country. Build. Environ. 2022, 207, 108487. [CrossRef]

5. Salehi, S.; Arashpour, M.; Kodikara, J.; Guppy, R. Sustainable pavement construction: A systematic literature review of environmental and economic analysis of recycled materials. J. Clean. Prod. 2021, 313, 127936. [CrossRef] 
6. Jaillon, L.; Poon, C.S. Sustainable construction aspects of using prefabrication in dense urban environment: A Hong Kong case study. Constr. Manag. Econ. 2008, 26, 953-966. [CrossRef]

7. Mohammadi Golafshani, E.; Arashpour, M.; Kashani, A. Green mix design of rubbercrete using machine learning-based ensemble model and constrained multi-objective optimization. J. Clean. Prod. 2021, 327, 129518. [CrossRef]

8. Brandão, R.; Hosseini, M.R.; Macêdo, A.N.; Melo, A.C.; Martek, I. Public administration strategies that stimulate reverse logistics within the construction industry: A conceptual typology. Eng. Constr. Archit. Manag. 2021. [CrossRef]

9. Adabre, M.A.; Chan, A.P.; Darko, A. A scientometric analysis of the housing affordability literature. J. Hous. Built Environ. 2021, 36, 1501-1533. [CrossRef]

10. Jin, R.; Hong, J.; Zuo, J. Environmental performance of off-site constructed facilities: A critical review. Energy Build. 2021, 207, 109567. [CrossRef]

11. Perkins, M. Torres Strait Leaders Sue Federal Government over Climate Change. The Sydney Morning Herald. 2021. Available online: https:/ / www.smh.com.au/environment/climate-change/torres-strait-leaders-sue-federal-government-over-climatechange-20211025-p592zo.html (accessed on 5 November 2021).

12. Ritchie, H.; Roser, M. Australia: $\mathrm{CO}_{2}$ Country Profile. University of Oxford. 2021. Available online: https://ourworldindata.org/ co2/country/australia (accessed on 5 November 2021).

13. Brady, J. In a Landmark Case, a Dutch Court Orders Shell to Cut Its Carbon Emissions Faster. NPR. 2021. Available online: https:/ / www.npr.org/2021/05/26/1000475878/in-landmark-case-dutch-court-orders-shell-to-cut-its-carbon-emissions-faster (accessed on 5 November 2021).

14. Nikmehr, B.; Hosseini, M.R.; Martek, I.; Zavadskas, E.K.; Antucheviciene, J. Digitalization as a Strategic Means of Achieving Sustainable Efficiencies in Construction Management: A Critical Review. Sustainability 2021, 13, 5040. [CrossRef]

15. Shooshtarian, S.; Hosseini, M.R.; Martek, I.; Shrestha, A.; Arashpour, M.; Costin, G.; Seaton, S. Australia's push to make residential housing sustainable-Do end-users care? Habitat Int. 2021, 114, 102384. [CrossRef]

16. Martek, I.; Hosseini, M.R.; Shrestha, A.; Zavadskas, E.K.; Seaton, S. The Sustainability Narrative in Contemporary Architecture: Falling Short of Building a Sustainable Future. Sustainability 2018, 10, 981. [CrossRef]

17. Wu, P.; Jin, R.; Xu, Y.; Lin, F.; Dong, Y.; Pan, Z. The analysis of barriers to BIM implementation for industrialized building construction: A China study. J. Civ. Eng. Manag. 2021, 27, 1-13. [CrossRef]

18. Stojčić, M.; Zavadskas, E.K.; Pamučar, D.; Stević, Ž.; Mardani, A. Application of MCDM Methods in Sustainability Engineering: A Literature Review 2008-2018. Symmetry 2019, 11, 350. [CrossRef]

19. Zavadskas, E.K.; Antucheviciene, J.; Vilutiene, T.; Adeli, H. Sustainable Decision-Making in Civil Engineering, Construction and Building Technology. Sustainability 2018, 10, 14. [CrossRef]

20. Zhu, X.; Meng, X.; Zhang, M. Application of multiple criteria decision making methods in construction: A systematic literature review. J. Civ. Eng. Manag. 2021, 27, 372-403. [CrossRef]

21. Zavadskas, E.K.; Govindan, K.; Antucheviciene, J.; Turskis, Z. Hybrid multiple criteria decision-making methods: A review of applications for sustainability issues. Econ. Res. Ekon. Istraživanja 2016, 29, 857-887. [CrossRef]

22. Wen, Z.; Liao, H.; Zavadskas, E.K.; Antuchevičienė, J. Applications of fuzzy multiple criteria decision making methods in civil engineering: A state-of-the-art survey. J. Civ. Eng. Manag. 2021, 27, 358-371. [CrossRef]

23. Fallahpour, A.; Wong, K.Y.; Rajoo, S.; Olugu, E.U.; Nilashi, M.; Turskis, Z. A fuzzy decision support system for sustainable construction project selection: An integrated FPP-FIS model. J. Civ. Eng. Manag. 2020, 26, 247-258. [CrossRef]

24. Mohandes, S.R.; Sadeghi, H.; Mahdiyar, A.; Durdyev, S.; Banaitis, A.; Yahya, K.; Ismail, S. Assessing construction labours' safety level: A fuzzy MCDM approach. J. Civ. Eng. Manag. 2020, 26, 175-188. [CrossRef]

25. Yazdani, M.; Wen, Z.; Liao, H.; Banaitis, A.; Turskis, Z. A grey combined compromise solution (CoCoSo-G) method for supplier selection in construction management. J. Civ. Eng. Manag. 2019, 25, 858-874. [CrossRef]

26. Kryvomaz, T.I.; Savchenko, A.M. The reducing of construction industry influence on climate change by implementation of green building principles. Environ. Saf. Nat. Resour. 2021, 37, 55-68. [CrossRef] 